\title{
Economics and Productivity of Hybrid Maize as Influenced by Combination of Gypsum and Borax under Different Nutrient Management Practices
}

\author{
B.R. Arunkumar", N. Srinivasa, S.S. Prakash and R. Krishna Murthy
}

Department of Soil science and Agricultural chemistry, College of Agriculture, V C Farm, Mandya, University of Agricultural Sciences, GKVK, Bengaluru-560 065, Karnataka, India

*Corresponding author

\section{A B S T R A C T}

\begin{tabular}{|l|}
\hline Ke y w or d s \\
Boron, Gypsum, \\
Maize, STCR, \\
Economics and \\
B: C ratio. \\
\hline Article Info \\
\hline Accepted: \\
17 July 2017 \\
Available Online: \\
10 September 2017 \\
\hline
\end{tabular}

Maize crop was raised in split plot design with different nutrient management practices as main and different levels of gypsum and borax as sub treatment. Main treatments included package of practices, UAS, Bengaluru $\left(\mathrm{M}_{1}\right)$, STCR dose for targeted yield of $90 \mathrm{q} \mathrm{ha}^{-1}$ $\left(\mathrm{M}_{2}\right)$ and STCR dose for targeted yield of $110 \mathrm{q} \mathrm{ha}^{-1}\left(\mathrm{M}_{3}\right)$ and sub treatments viz. control $\left(\mathrm{S}_{1}\right), 200 \mathrm{~kg}_{\text {gypsum ha }}{ }^{-1}\left(\mathrm{~S}_{2}\right), 2.5 \mathrm{~kg}$ borax ha ${ }^{-1}\left(\mathrm{~S}_{3}\right), 5 \mathrm{~kg}$ borax ha- ${ }^{-1}\left(\mathrm{~S}_{4}\right), 200 \mathrm{~kg}$ gypsum + $2.5 \mathrm{~kg}$ borax ha ${ }^{-1}\left(\mathrm{~S}_{5}\right)$ and $200 \mathrm{~kg}$ gypsum $+5 \mathrm{~kg}$ borax ha ${ }^{-1}\left(\mathrm{~S}_{6}\right)$. Among different nutrient management practices, $\mathrm{M}_{3}$ recorded significantly higher grain yield $\left(93.0 \mathrm{q} \mathrm{ha}^{-1}\right)$ with $15 \%$ deviation from targeted yield, stover yield $\left(184.25 \mathrm{q} \mathrm{ha}^{-1}\right)$ and higher grass net returns 134758.0 and 90589.0 Rs. ha ${ }^{-1}$ respectively was recorded in $\mathrm{M}_{3}$. However higher B: C ratio (3.21) was recorded in $\mathrm{M}_{2}$ over $\mathrm{M}_{1}$. Among gypsum and borax treatments, $\mathrm{S}_{4}$ recorded significantly higher grain yield $\left(89.86 \mathrm{q} \mathrm{ha}^{-1}\right)$, stover yield $\left(160.78 \mathrm{q} \mathrm{ha}^{-1}\right)$ and higher grass and net returns 129356.0 and 97999.0 Rs. ha ${ }^{-1}$ respectively and B: C ratio (3.41) compared to $S_{1}$ and $S_{2}$ and was on par with $S_{3}, S_{5}$ and $S_{6}$

\section{Introduction}

Maize (Zea mays L.) is one of the fourth important cereal crops next to rice, wheat and sorghum in the India and third important cereal crop in the world next to wheat and rice. It is known as "Queen of cereals" due to its great importance in human diet and also as cattle and poultry feed. Maize is cultivated in all seasons viz., kharif, rabi and summer with production $23.93 \mathrm{~m} \mathrm{t}$ from $9.4 \mathrm{~m}$ ha area with productivity of $2567 \mathrm{~kg} \mathrm{ha}^{-1}$ (Anon., 2014). The productivity and economics of maize is largely dependent on nutrient management and soil fertility status. Proper nutrient management is an important aspect in its production management system.
Applying the required quantities of nutrient at all stages of growth and understanding the soil's ability to supply those nutrients is critical in profitable crop production. Though the continuous use of fertilizers had significantly improved the crop productivity, heavy fertilizer application on the same plot every year in continuous maize system will drain the soil fertility rapidly and result in a plethora of problems viz., decline in crop productivity, deficiency of several micro nutrients, environmental pollution etc. The yield potential of our present maize verities and hybrids is high enough but it has not been explored fully due to some production 
constraints like indeterminate and imbalanced use of primary nutrients supplying fertilizers resulted in multiple nutrient deficiency particularly in the irrigated areas, that's affects the physico-chemical properties of soil and finally crop yield in terms of profit is reduced.

Calcium and boron play a pivotal role in increasing the yield of cereals. Calcium is a multifunctional nutrient in physiology of crop plants which helps in growth and development of plants and boron is an essential micronutrient required for better pollination, seed setting, growth and development of higher plants.

Therefore in order to sustain the profit and yield level integration or conjunctive use of secondary and micronutrients along with primary nutrients is very much essential.

The present study is proposed to study the economics and productivity of hybrid maize as influenced by combination of gypsum and borax under different nutrient management practices.

\section{Materials and Methods}

Field experiment was conducted during the kharif season of 2014 at College of Agricultural, V. C. Farm, Mandya, Karnataka. The experimental site was geographically situated at an altitude of $695 \mathrm{~m}$ above mean sea level, on $11^{\circ} 30^{\prime}$ to $13^{\circ} 05^{\prime}$ North latitude and $76^{\circ} 05^{\prime}$ to $77^{\circ} 45^{\prime}$ East longitude. It comes under Southern dry zone (Zone-6) of Karnataka. The soil was sandy loam in texture, neutral in soil reaction $(\mathrm{pH} 7.4)$ with normal in electrical conductivity $\left(0.23 \mathrm{dS} \mathrm{m}^{-1}\right)$ and $4.5 \mathrm{~g} \mathrm{~kg}^{-1}$ of organic matter, with low available nitrogen $\left(277 \mathrm{~kg} \mathrm{ha}{ }^{-1}\right)$, high available phosphorus (61 $\left.\mathrm{kg} \mathrm{ha}^{-1}\right)$ and medium potassium $\left(148 \mathrm{~kg} \mathrm{ha}^{-1}\right)$. The analytical values for some other nutrients were available sulphur (11.30 $\left.\mathrm{mg} \mathrm{kg}^{-1}\right)$, exchangeable calcium $\left(3.4 \mathrm{cmol} \mathrm{kg}^{-1}\right)$, DTPA extractable $\mathrm{Zn}\left(2.15 \mathrm{mg} \mathrm{kg}^{-1}\right)$ and hot water extractable boron $\left(0.4 \mathrm{mg} \mathrm{kg}^{-1}\right)$.

The experiment was laid out in split plot design with three replications. Three main treatments viz. package of practices (RDF) UAS(B) $\left(\mathrm{M}_{1}\right)$, STCR dose for targeted yield of $90 \mathrm{q} \mathrm{ha}^{-1}\left(\mathrm{M}_{2}\right)$ and STCR dose for targeted yield of $110 \mathrm{q} \mathrm{ha}^{-1}\left(\mathrm{M}_{3}\right)$ and six sub treatments viz. control $\left(\mathrm{S}_{1}\right), 200 \mathrm{~kg}$ gypsum $\mathrm{ha}^{-1}\left(\mathrm{~S}_{2}\right), 2.5 \mathrm{~kg}$ borax ha- $\left(\mathrm{S}_{3}\right), 5 \mathrm{~kg}$ borax ha ${ }^{-1}$ $\left(\mathrm{S}_{4}\right), 200 \mathrm{~kg}$ gypsum $+2.5 \mathrm{~kg}$ borax ha ${ }^{-1}\left(\mathrm{~S}_{5}\right)$ and $200 \mathrm{~kg}$ gypsum $+5 \mathrm{~kg}$ borax ha ${ }^{-1}\left(\mathrm{~S}_{6}\right)$. Fisher's method of analysis of variance was applied for analysis and interpretation of data to calculate the critical difference. The level of significance used in $f$ and $t$ test was $p=$ 0.05 or $5 \%$.

The quantity of fertilizers required for each treatment was worked out by three approaches such as recommended dose of fertilizer as per package of practices, UAS, Bengaluru, STCR dose of fertilizers for target of 90 and $110 \mathrm{q} \mathrm{ha}^{-1}$. Recommended fertilizer dose for hybrid maize under irrigated condition is $150: 75: 40 \mathrm{~N}: \mathrm{P}_{2} \mathrm{O}_{5}: \mathrm{K}_{2} \mathrm{O} \mathrm{kg} \mathrm{ha}^{-1}+$ zinc sulphate $10 \mathrm{~kg} \mathrm{ha}^{-1}+10 \mathrm{t}$ FYM ha ${ }^{-1}$ (package of practice, UAS, Bengaluru).

The following fertilizer adjustment equations developed by AICRP on STCR, UAS, Bengaluru were used to work out the fertilizer dose for 90 and $110 \mathrm{q} \mathrm{ha}^{-1}$ yield target.

$\mathrm{FN}=3.41 \mathrm{~T}-0.08 \mathrm{SN}\left(\mathrm{KMnO}_{4}-\mathrm{N}\right)$

$\mathrm{FP}_{2} \mathrm{O}_{5}=1.94 \mathrm{~T}-0.41 \mathrm{SP}_{2} \mathrm{O}_{5}\left(\right.$ Bray's $\left.\mathrm{P}_{2} \mathrm{O}_{5}\right)$

$\mathrm{FK}_{2} \mathrm{O}=2.28 \mathrm{~T}-0.072 \mathrm{SK}_{2} \mathrm{O}\left(\mathrm{NH}_{4} \mathrm{OAC}-\right.$ $\mathrm{K}_{2} \mathrm{O}$ )

\section{Gross returns (Rs. ha $\left.{ }^{-1}\right)$}

Gross returns were calculated by multiplying the grain and straw yield with their respective 
prevailing market prices (Perin et al., 1979) and presented as $\mathrm{ha}^{-1}$.

\section{Net returns (Rs. ha $\left.{ }^{-1}\right)$}

The net returns were calculated by subtracting the cost of cultivation from the gross returns and presented as $\mathrm{ha}^{-1}$.

\section{Benefit: $\operatorname{cost}(\mathrm{B}: \mathrm{C})$ ratio}

Benefit cost ratio was worked out by using the following formula

$$
\begin{aligned}
& \text { Gross returns (Rs. ha }{ }^{-1} \text { ) } \\
& \begin{array}{r}
\text { Benefit: cost ratio }=---------------1) \\
\text { Cost of cultivation }\left(\text { Rs. } \text { ha }^{-1}\right)
\end{array}
\end{aligned}
$$

\section{Results and Discussion}

\section{Yield attributes of maize}

The increase in grain yield due to nutrient management practices and different combination of gypsum and borax application in sub plot treatments could be attributed to proportionate increase in yield parameters such as cob length, number of rows per cob, number of grains per cob and test weight (Table 1).

Among the different nutrient management practices STCR dose recommended for yield target of $110 \mathrm{q} \mathrm{ha}^{-1}\left(\mathrm{M}_{3}\right)$ recorded higher cob length, number of rows per cob, number of grains per cob and test weight $18.001 \mathrm{~cm}$, $16.96,540.77$ and $32.22 \mathrm{~g}$ respectively compare with STCR dose recommended for yield target of $90 \mathrm{q} \mathrm{ha}^{-1}\left(\mathrm{M}_{2}\right)$ and package of practice $\left(\mathrm{M}_{1}\right)$, resulting in higher grain yield. These results are in conformity with Shivashankar and Sudhakar Babu (1994).

In sub treatments $\mathrm{S}_{5}$ recorded higher cob length of $17.17 \mathrm{~cm}$, whereas $S_{4}$ recorded more number of rows per cob (17.14), number of grains per cob (573.06) and test weight of $31.87 \mathrm{~g}$, ultimately resulting in higher grain yield in sub treatment $\mathrm{S}_{4}$. Application of borax individually helped in increasing the above yield parameters. The combination of borax with gypsum has not helped the cause and it could be due to interaction effect of calcium and boron. Muhammad (2013) has reported that application of boron significantly increased the cob length, number of rows per cob, grains per cob and test weight. The boron content of experimental soil was $0.4 \mathrm{ppm}$ which is deficient. Application of borax at $5 \mathrm{~kg} \mathrm{ha}^{-1}$ has resulted in good response of yield parameters in maize.

\section{Grain and stover yield (q ha $\left.{ }^{-1}\right)$ and harvest index of maize}

The data on grain yield $\left(\mathrm{q} \mathrm{ha}^{-1}\right)$, stover yield $\left(\mathrm{q} \mathrm{ha}^{-1}\right.$ ) and harvest index of maize as influenced by different treatments under the study are presented in table 2 .

Among main treatments, $\mathrm{M}_{3}\left(110 \mathrm{q} \mathrm{ha}^{-1}\right.$ target) targeted yield was not achieved, it fell short by nearly $15 \%$.

However, it recorded significantly higher maize grain and stover yield (93.00 and $184.25 \mathrm{q} \mathrm{ha}^{-1}$ ) over $\mathrm{M}_{1}(66.69$ and $115.82 \mathrm{q}$ $\mathrm{ha}^{-1}$ ), respectively. In $\mathrm{M}_{2}$ targeted yield was achieved. This was on par with $\mathrm{M}_{3}$ and it was significantly higher than that observed in $\mathrm{M}_{1}$ (66.69 $\mathrm{q} \mathrm{ha}^{-1}$ ) and the harvest index ranged between 0.37 with package of practice to 0.34 with STCR approach for targeted yield $110 \mathrm{q}$ $\mathrm{ha}^{-1}$. This could be attributed due to luxuriant growth in $\mathrm{M}_{3}$ plots resulting in higher stover yield and higher stover to grain ratio, which has finally resulted in lesser conversion rate from source to sink. This could be also the reason for lower harvest index in $\mathrm{M}_{3}$. This was evidenced through findings of Jayaprakash $e t$ al., (2006). 
Significantly higher grain yield was recorded in $S_{4}\left(89.86 \mathrm{q} \mathrm{ha}^{-1}\right)$ treatment which received borax at $5 \mathrm{~kg} \mathrm{ha}^{-1}$ and it was on par with $\mathrm{S}_{3}$ (87.34 q ha $\mathrm{q}^{-1}$ and lower grain yield was recorded in $\mathrm{S}_{1}\left(73.01 \mathrm{q} \mathrm{ha}^{-1}\right)$. However, significantly higher stover yield of $168.61 \mathrm{q}$ ha $^{-1}$ was recorded inS $S_{5}$. Lower stover yield was in $S_{1}\left(129.56 \mathrm{q} \mathrm{ha}^{-1}\right.$ ) compared to $\mathrm{S}_{2}, \mathrm{~S}_{3}$ and $\mathrm{S}_{4}$ treatments and sub treatments, significantly higher harvest index was recorded with $S_{1}, S_{3}$ and $S_{4}$ (0.36) and significantly lower harvest index was recorded with $S_{5}(0.33)$. This could again be due to high dry matter in $S_{5}$ due to high stover yield but lesser conversion rate from source to sink. Mohamad (2014) and Sarkaut et al., (2013) have reported that application of boron significantly increased the yield of maize due to increase in pollination and seed setting.

Interaction due to different nutrient management practices with application of gypsum and boron did not show any significant effect on grain and stover yield and harvest index of maize crop.

\section{Economics}

Economics analysis was carried out by considering the cost prevailed during the cropping period of 2014 and also by considering the cost of FYM, inorganic fertilizers and plant protection chemicals. The cost incurred and profits derived are calculated and presented in table 3 .

\section{Cost of cultivation}

Economic analysis revealed that, among main plot treatments highest cost of cultivation Rs. $44169.0 \mathrm{ha}^{-1}$ was recorded in $\mathrm{M}_{3}$ treatment, where fertilizers are applied based on STCR targeted yield of $110 \mathrm{q} \mathrm{ha}^{-1}$ and lowest cost of cultivation Rs. $30426.0 \mathrm{ha}^{-1}$ was recorded in treatment $\mathrm{M}_{1} \mathrm{UAS}$, Bengaluru, package of practice treatment.
Among sub plots highest cost of cultivation Rs. 38908.0 ha $^{-1}$ was recorded in $S_{6}$ treatment (200 kg gypsum and $5 \mathrm{~kg}$ borax $\mathrm{ha}^{-1}$ ) and lowest Rs. 37388.0 ha $^{-1}$ was recorded in $S_{1}$ (control).

\section{Gross returns}

Among different nutrient management practices application of fertilizers by STCR based targeted yield of $110 \mathrm{q} \mathrm{ha}^{-1}$ recorded higher gross returns (Rs. 134758.0) followed by STCR based targeted yield of $90 \mathrm{q} \mathrm{ha}^{-1}$ (Rs. 128057.0). The cost of cultivation of maize under targeted yield approaches varied from treatment to treatment due to varied amount of fertilizer application and their cost.

The cost of cultivation of maize was high in STCR based targeted yield of $110 \mathrm{q} \mathrm{ha}^{-1}$ (Rs. $44169.0 \mathrm{ha}^{-1}$ ) followed by STCR based targeted yield of $90 \mathrm{q} \mathrm{ha}^{-1}$ (Rs. $39848.0 \mathrm{ha}^{-1}$ ) due to application of higher quantity of fertilizers as per requirement.

Among subplot treatments, application of 5 $\mathrm{kg}$ of borax recorded higher gross returns (Rs. 129356.0) followed by application of $2.5 \mathrm{~kg}$ borax ha' ${ }^{-1}$ (Rs. 125648.0).

The cost of cultivation of maize under gypsum and borax application varied from treatment to treatment due to varied amount of application of inputs and their cost.

The cost of cultivation of maize was high in $200 \mathrm{~kg}$ gypsum and $5 \mathrm{~kg}$ borax $\mathrm{ha}^{-1}$ treated plot (Rs. $38908.0 \mathrm{ha}^{-1}$ ) followed by $200 \mathrm{~kg}$ gypsum and $2.5 \mathrm{~kg}$ borax ha ${ }^{-1}$ treated plot (Rs. $38533.0 \mathrm{ha}^{-1}$ ) due to application of higher amount of gypsum and borax fertilizer and their cost.

These results are in agreement with the findings of Apoorva et al., (2010) and Ashok and Jayadeva (2013). 
Table.1 Cob length, number of rows per cob, number of grains per cob and test weight of maize as influenced by application of gypsum and borax under different nutrient management practices

\begin{tabular}{|c|c|c|c|c|c|}
\hline \multicolumn{2}{|c|}{ Treatments } & $\begin{array}{c}\text { Cob length } \\
(\mathrm{cm})\end{array}$ & $\begin{array}{c}\text { Number of rows } \\
\text { per cob }\end{array}$ & $\begin{array}{c}\text { Number of } \\
\text { grains per cob }\end{array}$ & $\begin{array}{c}\text { Test weight } \\
\text { (g) }\end{array}$ \\
\hline \multicolumn{2}{|c|}{$\mathrm{M}_{1}$} & 15.12 & 15.02 & 433.88 & 26.99 \\
\hline \multicolumn{2}{|c|}{$\mathrm{M}_{2}$} & 16.46 & 16.63 & 526.96 & 31.22 \\
\hline \multicolumn{2}{|c|}{$\mathrm{M}_{3}$} & 18.01 & 16.96 & 540.77 & 32.22 \\
\hline \multicolumn{2}{|c|}{ S.Em \pm} & 0.28 & 0.35 & 18.17 & 0.97 \\
\hline \multicolumn{2}{|c|}{$\mathrm{CD}(\mathrm{p}=0.05)$} & 1.09 & 1.38 & 71.35 & 3.80 \\
\hline \multicolumn{2}{|c|}{$\mathrm{S}_{1}$} & 15.73 & 14.83 & 408.89 & 28.24 \\
\hline \multicolumn{2}{|c|}{$\mathrm{S}_{2}$} & 15.83 & 15.37 & 456.18 & 28.96 \\
\hline \multicolumn{2}{|c|}{$\mathrm{S}_{3}$} & 16.78 & 16.67 & 535.79 & 31.31 \\
\hline \multicolumn{2}{|c|}{$\mathrm{S}_{4}$} & 16.85 & 17.14 & 573.06 & 31.87 \\
\hline \multicolumn{2}{|c|}{$\mathrm{S}_{5}$} & 17.17 & 16.23 & 495.66 & 30.21 \\
\hline \multicolumn{2}{|c|}{$\mathrm{S}_{6}$} & 16.82 & 16.97 & 533.65 & 30.27 \\
\hline \multicolumn{2}{|c|}{ S.Em \pm} & 0.72 & 0.46 & 13.88 & 0.77 \\
\hline \multicolumn{2}{|c|}{$\mathrm{CD}(\mathrm{p}=\mathbf{0 . 0 5})$} & NS & 1.33 & 40.10 & 2.33 \\
\hline \multirow{2}{*}{$\begin{array}{c}\text { Interaction } \\
\text { M X S }\end{array}$} & S.Em \pm & 0.421 & 0.81 & 85.26 & 4.72 \\
\hline & $\mathrm{CD}(\mathrm{p}=\mathbf{0 . 0 5})$ & NS & NS & NS & NS \\
\hline
\end{tabular}

Table.2 Grain yield, stover yield and harvest index of maize as influenced by application of gypsum and borax under different nutrient management practices

\begin{tabular}{|c|c|c|c|c|}
\hline \multicolumn{2}{|c|}{ Treatments } & $\begin{array}{c}\text { Grain yield } \\
\left(\mathbf{q} \mathbf{h a}^{-1}\right)\end{array}$ & $\begin{array}{c}\text { Stover yield } \\
\left(\mathrm{q} \mathrm{ha}^{-1}\right)\end{array}$ & Harvest index \\
\hline \multicolumn{2}{|c|}{$\mathrm{M}_{1}$} & 66.69 & 115.82 & 0.37 \\
\hline \multicolumn{2}{|c|}{$\mathrm{M}_{2}$} & 88.78 & 164.14 & 0.35 \\
\hline \multicolumn{2}{|c|}{$\mathrm{M}_{3}$} & 93.00 & 184.25 & 0.34 \\
\hline \multicolumn{2}{|c|}{ S.Em \pm} & 0.89 & 1.99 & 0.01 \\
\hline \multicolumn{2}{|c|}{$C D(p=0.05)$} & 6.22 & 7.82 & 0.01 \\
\hline \multicolumn{2}{|c|}{$\mathrm{S}_{1}$} & 73.01 & 129.56 & 0.36 \\
\hline \multicolumn{2}{|c|}{$\mathrm{S}_{2}$} & 80.95 & 149.64 & 0.35 \\
\hline \multicolumn{2}{|c|}{$\mathrm{S}_{3}$} & 87.34 & 154.69 & 0.36 \\
\hline \multicolumn{2}{|c|}{$\mathrm{S}_{4}$} & 89.86 & 160.78 & 0.36 \\
\hline \multicolumn{2}{|c|}{$\mathrm{S}_{5}$} & 82.23 & 168.61 & 0.33 \\
\hline \multicolumn{2}{|c|}{$\mathrm{S}_{6}$} & 81.94 & 165.14 & 0.34 \\
\hline \multicolumn{2}{|c|}{ S.Em \pm} & 1.05 & 1.95 & 0.01 \\
\hline \multicolumn{2}{|c|}{$\mathrm{CD}(\mathrm{p}=0.05)$} & 7.30 & 5.64 & 0.02 \\
\hline \multirow{2}{*}{$\begin{array}{c}\text { Interaction } \\
\text { MX S }\end{array}$} & S.Em \pm & 1.89 & 11.89 & 0.04 \\
\hline & $C D(p=0.05)$ & NS & NS & NS \\
\hline
\end{tabular}


Table.3 Cost of cultivation, gross returns, net returns and benefit cost ratio in irrigated maize as influenced by Different approaches of fertilizer prescriptions

\begin{tabular}{|c|c|c|c|c|c|c|c|c|c|c|c|c|c|c|c|c|}
\hline \multirow{2}{*}{ Treatments } & \multicolumn{4}{|c|}{ Cost of cultivation (Rs. ha ${ }^{-1}$ ) } & \multicolumn{4}{|c|}{ Gross returns (Rs. ha $\left.{ }^{-1}\right)$} & \multicolumn{4}{|c|}{ Net returns (Rs. ha' $\left.{ }^{-1}\right)$} & \multicolumn{4}{|c|}{ B: C ratio } \\
\hline & $\mathbf{M}_{1}$ & $\mathbf{M}_{2}$ & $\mathbf{M}_{3}$ & Mean & $\mathbf{M}_{1}$ & $\mathbf{M}_{2}$ & $\mathbf{M}_{3}$ & Mean & $\mathbf{M}_{1}$ & $\mathbf{M}_{2}$ & $\mathbf{M}_{3}$ & Mean & $\mathbf{M}_{1}$ & $\mathbf{M}_{2}$ & $\mathbf{M}_{3}$ & Mean \\
\hline $\mathbf{S}_{1}$ & 29666 & 39088 & 43409 & 37388 & 81690 & 110941 & 122506 & 105046 & 52025 & 71853 & 79097 & 67658 & 2.75 & 2.84 & 2.82 & 2.80 \\
\hline $\mathbf{S}_{2}$ & 30436 & 39858 & 44179 & 38158 & 88665 & 127602 & 134017 & 116761 & 58230 & 87744 & 89838 & 78604 & 2.93 & 3.20 & 3.03 & 3.06 \\
\hline $\mathbf{S}_{\mathbf{3}}$ & 30041 & 39461 & 43784 & 37762 & 104559 & 134555 & 137832 & 125648 & 74518 & 95091 & 94047 & 87886 & 3.48 & 3.41 & 3.15 & 3.35 \\
\hline $\mathbf{S}_{\mathbf{4}}$ & 30416 & 39838 & 44159 & 38138 & 106130 & 139781 & 142157 & 129356 & 75714 & 99942 & 97998 & 91218 & 3.49 & 3.51 & 3.22 & 3.41 \\
\hline $\mathbf{S}_{5}$ & 30811 & 40233 & 44554 & 38533 & 96145 & 128870 & 135726 & 120247 & 65334 & 88636 & 91171 & 81714 & 3.12 & 3.20 & 3.05 & 3.12 \\
\hline $\mathbf{S}_{6}$ & 31186 & 40608 & 44929 & 38908 & 97769 & 126594 & 136311 & 120224 & 66583 & 85986 & 91382 & 81317 & 3.14 & 3.12 & 3.03 & 3.10 \\
\hline Mean & 30426 & 39848 & 44169 & 38147 & 95826 & 128057 & 134758 & 119547 & 65401 & 88209 & 90589 & 81399 & 3.15 & 3.21 & 3.05 & 3.14 \\
\hline
\end{tabular}




\section{Net returns}

Among different nutrient management practices application of fertilizers by STCR based targeted yield of $110 \mathrm{q} \mathrm{ha}^{-1}$ recorded higher net returns (Rs. 90589.0) followed by STCR based targeted yield of $90 \mathrm{q} \mathrm{ha}^{-1}$ (Rs. 88209.0). The cost of cultivation of maize under targeted yield approaches varied from treatment to treatment due to varied amount of fertilizer application and their cost. The cost of cultivation of maize was high in STCR based targeted yield of $110 \mathrm{q} \mathrm{ha}^{-1}$ (Rs. $44169.0 \mathrm{ha}^{-1}$ ) followed by STCR based targeted yield of $90 \mathrm{q} \mathrm{ha}^{-1}$ (Rs. $39848.0 \mathrm{ha}^{-1}$ ) due to application of higher quantity of fertilizers as per requirement.

Among subplot treatments, application of 5 $\mathrm{kg}$ of borax recorded higher net returns (Rs. $97999.0 \mathrm{ha}^{-1}$, respectively) followed by application of $2.5 \mathrm{~kg}$ borax ha ${ }^{-1}$ (Rs. 87886.0 $\left.\mathrm{ha}^{-1}\right)$. The cost of cultivation of maize under gypsum and borax application varied from treatment to treatment due to varied amount of application of inputs and their cost.

The cost of cultivation of maize was high in $200 \mathrm{~kg}$ gypsum and $5 \mathrm{~kg}$ borax $\mathrm{ha}^{-1}$ treated plot (Rs. $38908.0 \mathrm{ha}^{-1}$ ) followed by $200 \mathrm{~kg}$ gypsum and $2.5 \mathrm{~kg}$ borax $\mathrm{ha}^{-1}$ treated plot (Rs. $38533.0 \mathrm{ha}^{-1}$ ) due to application of higher amount of gypsum and borax fertilizer and their cost.

These results are in agreement with the findings of Apoorva et al., (2010) and Ashok and Jayadeva (2013).

\section{B: C ratio}

Application of fertilizers based on STCR targeted yield $90 \mathrm{q} \mathrm{ha}^{-1}$ recorded higher B: C ratio (3.21) then with UAS, Bengaluru, package of practice (3.15) and STCR targeted yield level of $110 \mathrm{q} \mathrm{ha}^{-1}$ (3.05).
Among sub plots application of $5 \mathrm{~kg}$ of borax $\left(\mathrm{S}_{4}\right)$ recorded higher B: C ratio (3.41) compared to other treatments and lowest B: C ratio of 2.80 was recorded in control $\left(\mathrm{S}_{1}\right)$ treatment.

Benefit cost ratio is higher in STCR based targeted yield of $90 \mathrm{q} \mathrm{ha}^{-1}$ (3.21) followed by STCR based targeted yield of $110 \mathrm{q} \mathrm{ha}^{-1}$ (3.05). This is mainly due to low quantity of fertilizers used in the treatment targeted for 90 $\mathrm{q} \mathrm{ha}^{-1}$ compared to $110 \mathrm{q} \mathrm{ha}^{-1}$ targeted yield. Further, it was evidenced by low cost of cultivation (Table 3 ).

Benefit cost ratio is higher in $5 \mathrm{~kg}$ borax $\mathrm{ha}^{-1}$ (3.41) followed by $2.5 \mathrm{~kg}$ borax ha ${ }^{-1}$ (3.35) and lowest cost of cultivation, gross returns, net returns and $\mathrm{B}$ : $\mathrm{C}$ ratio was recorded in control plot. The results are in conformity with the findings Apoorva et al., (2010) and Ashok and Jayadeva (2013).

Among interaction between main and sub treatments application of $5 \mathrm{~kg}$ of borax with STCR for targeted yield level of $90 \mathrm{q} \mathrm{ha}^{-1}\left(\mathrm{M}_{2}\right.$ $\times \mathrm{S}_{4}$ ) recorded higher $\mathrm{B}: \mathrm{C}$ ratio (3.51) than with STCR targeted yield levels of $110 \mathrm{q} \mathrm{ha}^{-1}$ and UAS, Bengaluru, package of practice treatments. Lowest B: C ratio (2.75) was recorded in control treatment with UAS, Bengaluru, package of practice treatment $\left(\mathrm{M}_{1}\right.$ $\left.\times \mathrm{S}_{1}\right)$.

\section{References}

Anonymous, 2014. Area, production and productivity of major cereals in India. www.indiastat.com.

Apoorva, K. B., Prakash, S. S., Rajesh, N. L. and Nandini, B. 2010. STCR approach for optimizing integrated plant nutrient supply on growth, yield and economics of Finger Millet (Eleusine coracana L. Garten.). J. Bio. Sci., 4(1): 19-27.

Ashok, B., and Jayadeva, H. M. 2013. 
Influence of targeted yield approach on yield, yield attributes, nutrient uptake and economics of maize. Madras Agricult. J., 100(1-3): 146-149.

Jayaprakash, T.C., nagalikar, V.P., pujari, B.T. and Shetty, R.A. 2006. Effect of organics and inorganics on growth and yield of maize under irrigation. Karnataka J. Agricult. Sci., 18(3): 794798.

Mohamed, S.H., 2014. Dynamics of boron in soils and response of maize-cowpea to graded levels of boron in central dry zone of Karnataka. Ph.D. Thesis. University of Agricultural Sciences, Bengaluru, India.

Muhammad, A., 2013. Cumulative effect of sulphur and calcium on wheat growth and yield under saline-sodic soils.
Pakistan J. Agricult. Res., 26(1): 46-53. Perin, R.K., Donald. L.W., Edwards, R.M and Jack, R.A. 1979. From Agronomic data for farmer recommendations. $A n$ Economic Training Manual, CIMMYT Information Bulletin. 27: 15-33.

Sarkaut, S., Salaheddin, M., Kaivan, A. N. and Anvar, R. A. 2013. Growth and yield response of maize (Zea mays L.) to different rates of potassium and boron. Int. J. Agricult. Crop Sci., 5(3): 236-240.

Shivashankar, K.A., and Sudhakar Babu S N. 1994. Influence of organic matter, spacing and fertilizer levels on growth and yield of maize. Proc: Seminar on technology for sustainable crop production IAT. Bengaluru.

\section{How to cite this article:}

Arunkumar, B.R., N. Srinivasa, S.S. Prakash and Krishna Murthy, R. 2017. Economics and Productivity of Hybrid Maize as Influenced by Combination of Gypsum and Borax under Different Nutrient Management Practices. Int.J.Curr.Microbiol.App.Sci. 6(9): 1112-1119. doi: https://doi.org/10.20546/ijcmas.2017.609.133 